\title{
Reflections on almost a century of hydrological studies on Africa's largest lake
}

\author{
Kevin Sene ${ }^{1}$, Helen Houghton Carr $^{2}$, and Wlodek Tych ${ }^{1}$ \\ ${ }^{1}$ Lancaster Environment Centre, Lancaster, LA1 4YQ, UK \\ ${ }^{2}$ UK Centre for Ecology \& Hydrology, Wallingford, OX10 8BB, UK \\ Correspondence: Kevin Sene (k.sene1@lancaster.ac.uk) \\ Published: 16 November 2021
}

\begin{abstract}
Lake Victoria is the largest lake in Africa and its outflows strongly influence flows in the White Nile, including the availability of water for hydropower generation, irrigation and water supply. Understanding the water balance is a major challenge since the lake is large enough to influence the local climate and its catchment spans several countries. Hydrometeorological monitoring networks are also sparse in some parts of the basin. In this paper, we consider the history of water balance estimates for the lake and how the science has developed as new information and techniques have become available, including in areas such as seasonal flow forecasting and estimating the potential impacts of dam operations and climate change. These findings are placed into a wider context including the challenges arising from a changing climate and evolving ideas from international research programmes, which lead to some suggestions for future research priorities for Lake Victoria and other sub-Saharan/Rift Valley lakes.
\end{abstract}

\section{Introduction}

Lake Victoria is the largest lake in Africa and the main source of water for the White Nile. It has a mean surface area of approximately $68000 \mathrm{~km}^{2}$ and the surrounding catchment area is more than three times as large, at about $194000 \mathrm{~km}^{2}$ (e.g. WMO, 1974, 1982). Inflows to the lake arise from Rwanda, Burundi, Kenya, Tanzania, Uganda, and the Democratic Republic of the Congo.

Whilst the hydrology of the lake has been surveyed since the early 20th century, the first significant studies were associated with the design of Owen Falls (now Nalubaale) Dam which was commissioned in 1953. Typically, these focused on the long-term water balance of the lake (Sutcliffe and Parks, 1999) but, by the 1970s, several computer simulation studies had been conducted using raingauge averaging methods to estimate lake and catchment rainfall, and conceptual rainfall-runoff models to estimate ungauged inflows. Pioneering work had also been performed on the use of stochastic models to estimate future outflows. Piper et al. (1986) provide a useful overview of techniques in use at that time.
More recently, novel approaches have been developed to meet the challenges of new applications, such as for shortrange weather forecasting, seasonal flow forecasting, and assessing the potential impacts of climate change. The hydropower generating capacity of the White Nile also continues to be exploited further, with several schemes now along the river. The techniques used have included regional and mesoscale atmospheric models, and stochastic approaches, as discussed later.

Following a brief literature review, this paper presents insights into how modelling techniques have evolved over the decades and some key lessons learned. This includes perspectives gained from new applications in areas such as climate change, seasonal flow forecasting and assessing the impacts of dam operations. These findings are then placed into a wider context including the challenges arising from a changing climate and evolving ideas from international research programmes. 


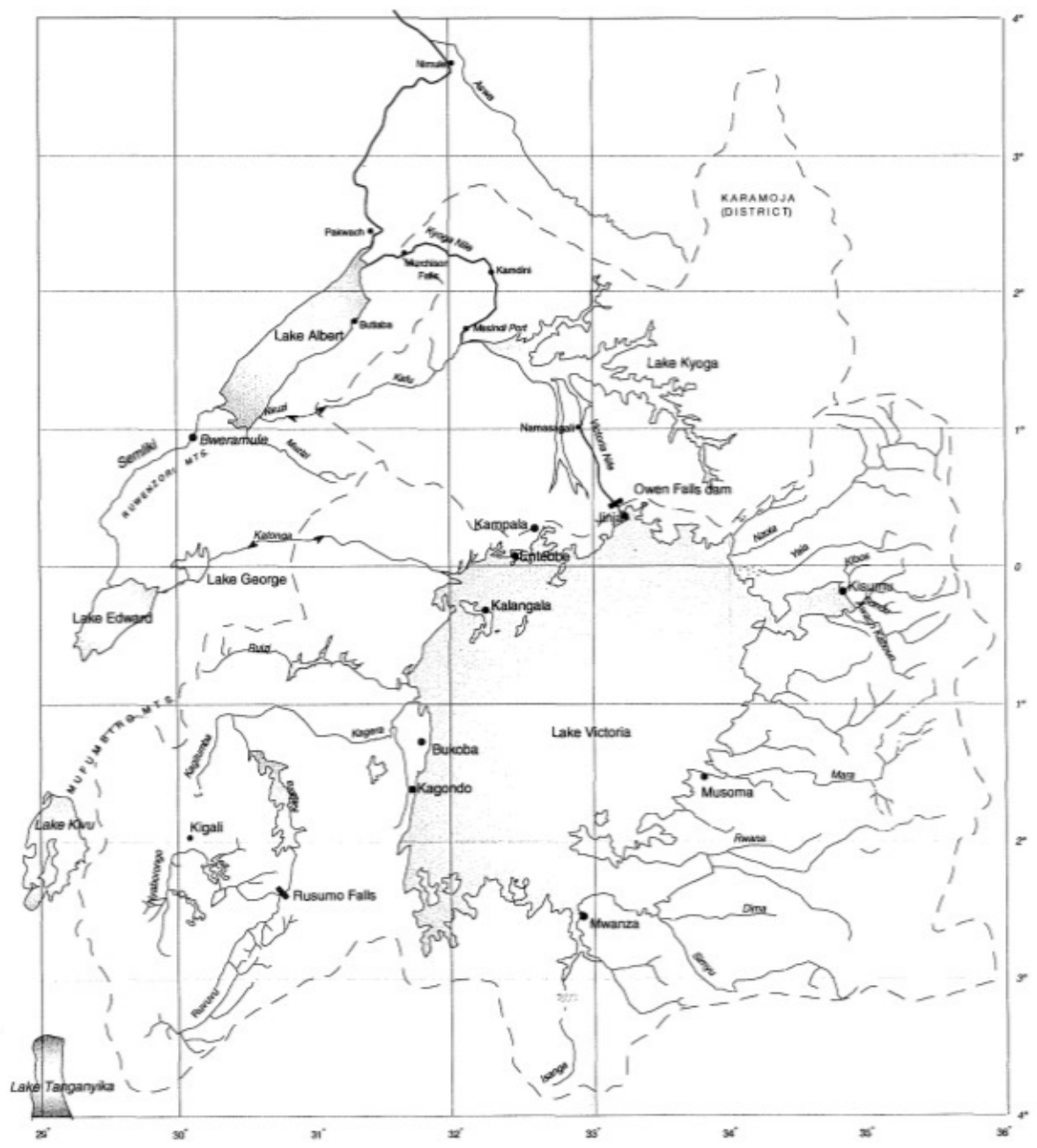

Figure 1. Map of the lake region (source: IAHS Press and Sutcliffe and Parks, 1999).

\section{The study area}

Figure 1 shows the location of Lake Victoria. The lake rainfall is dominated by the annual progression of the Intertropical Convergence Zone resulting in two rainfall seasons, although lake temperature influences are large enough to affect the local atmospheric circulation.

Regular lake level observations began in the 1890s. Some raingauge observations started in the following decade, whilst routine monitoring of outflows commenced in the 1940s. Monitoring reached a peak during the landmark World Meteorological Organisation (WMO) Hydrometeorological Survey of the 1960s, 1970s and 1980s. More recently, there been major improvements associated with regional bodies such as the Lake Victoria Basin Commission (LVBC) and the Nile Basin Initiative (NBI).

Figure 2 shows the lake level variations from 1896 to 2017. An interesting feature is how seasonal variations in levels are superimposed on much longer-term storage influences, meaning that long record lengths, over periods of decades, are required to understand the lake response.

The water balance for a lake can be expressed as Eq. (1):

$A \Delta h=A N-Q_{\mathrm{o}}$

where $A$ is the surface area, $\Delta h$ is the change in water level in a time interval, $N$ is the net inflow and $Q_{\mathrm{o}}$ is the lake outflow (e.g. Piper et al., 1986). The term $N$ is sometimes called the Net Basin Supply (NBS) and is given by Eq. (2):

$N(t)=P(t)-E(t)+\frac{Q_{\mathrm{i}}(t)}{A(t)}+\epsilon(t)=\Delta h+\frac{Q_{\mathrm{o}}(t)}{A(t)}$

where $t$ is time, $P$ is the lake rainfall, $E$ is the lake evaporation and $Q_{\mathrm{i}}$ is the tributary inflow. The surface area is often assumed to be constant whilst the additional term $\epsilon$ represents relatively minor items which are usually neglected as they are difficult to estimate, such as water abstractions and groundwater seepage. 


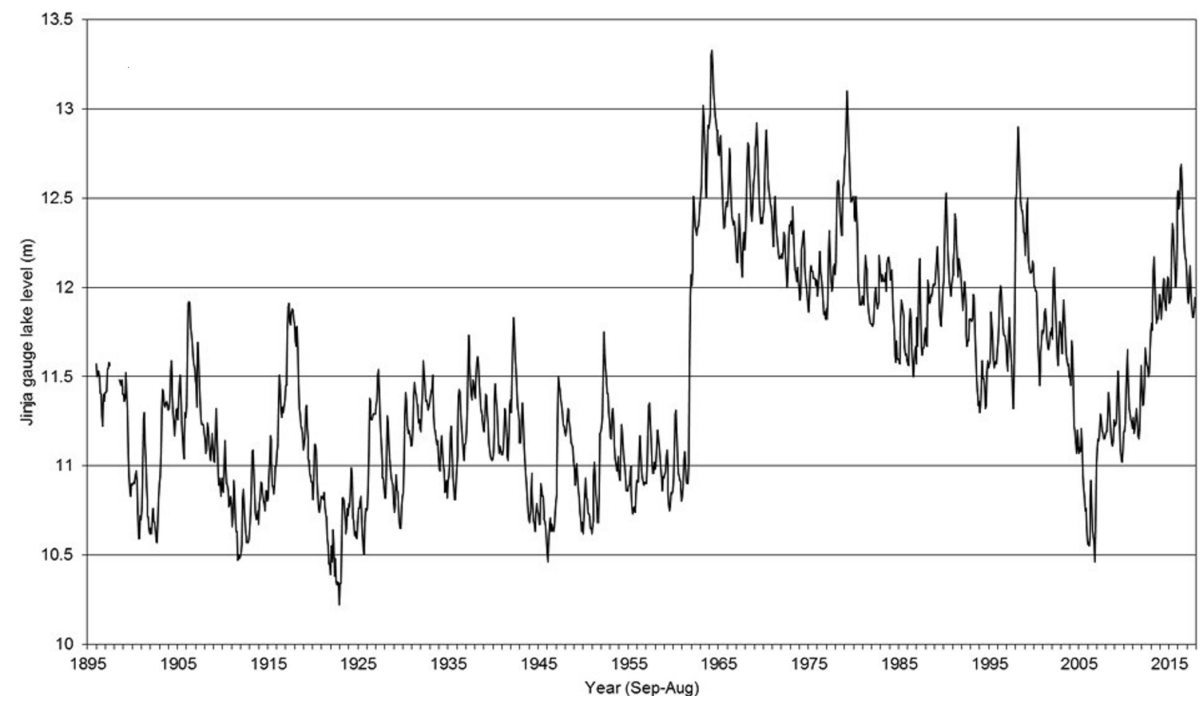

Figure 2. Lake Victoria water levels from 1896 to 2017 (source: NCSU et al., 2018).

In some studies, an empirical rainfall scaling term, $c$, is introduced so that the net basin supply can be expressed as Eqs. (3) or (4):

$N=c P-E+Q_{\mathrm{i}} / A$

$N=c(P-E)+Q_{\mathrm{i}} / A$.

This value is then estimated by specifying closure of the water balance over the chosen calibration period, with a further refinement being to consider individual factors for each of the monitoring stations considered.

\section{Modelling challenges}

\subsection{Water balance approaches}

Given the importance of Lake Victoria in the region, there have been numerous studies of its water balance; far too many to list here. Table 1 presents some landmark studies, selected both for the techniques considered and the large number of citations they include. Additional references appear later for specific applications.

Of the terms in the water balance, the direct rainfall on the lake surface provides the majority of the input but is the most difficult component to estimate. Typically, this is achieved by area-weighting raingauge observations although, as noted in the table, recent studies are increasingly using satellite precipitation estimates. However, one challenge with both approaches is that the lake is large enough to affect the local atmospheric circulation, causing rainfall to be higher over the water surface. This means that raingauge observations, even from the lakeshore, may not be representative, whilst the interpretation of satellite observations is made more challenging due to the impacts of enhanced cloud cover over the lake, affecting both rainfall and water temperatures.
The lake evaporation is another important component and is typically estimated from a Penman-type approach using observations from weather stations. As with raingauge observations, the local atmospheric circulation introduces additional uncertainty, with the added complication that there are relatively few weather stations. However, as might be expected, evaporation is much less variable than rainfall so often a long-term monthly average is assumed in simulations.

The tributary inflows, in comparison, are relatively small, but many studies have noted that much of the variability in lake levels arises from this term, due to the fine balance between lake rainfall and evaporation, which are of a similar magnitude. However, many of the tributaries are ungauged or have short record lengths, making rainfall-runoff model calibration difficult for infilling and extending records. Fortunately, though, the longest and best quality records are for the main rivers which flow into the lake, so the combined inflow from these rivers is often scaled to estimate the total inflow. For example, the catchments of the Kagera, which flows into the lake from Tanzania to the west, and the Nzoia, Yala, Sondu and Awash Kaboun from Kenya to the northeast, represent about $40 \%$ of the total catchment area.

Given these challenges, one innovative aspect in many studies of Lake Victoria has been the recognition that much can be understood about the lake response by considering the NBS alone, estimated from lake levels and outflows. This approach has the attraction that both terms are monitored with greater precision than the inflow components so that, in principle, estimates should be more accurate. Also, since level records now span more than a century, there is the benefit of a dataset that represents a wide range of historical lake levels and their frequencies of occurrence. Linked to this, another innovation was the early adoption of stochastic models for the NBS to explore variations in future levels. 
Table 1. Summary of key investigations of the water balance of Lake Victoria.

\begin{tabular}{|c|c|}
\hline Publication date & Findings \\
\hline 1938 & $\begin{array}{l}\text { First published attempt to close lake water balance, } \\
\text { based on minimal observations from around the lake } \\
\text { (Hurst and Phillips, 1938) }\end{array}$ \\
\hline 1970 & $\begin{array}{l}\text { Technical note to Uganda Water Development Dept } \\
\text { including a first lake rainfall series (De Baulny and } \\
\text { Baker, 1970) }\end{array}$ \\
\hline 1974-1982 & $\begin{array}{l}\text { Initiated systematic measurements of tributary inflows } \\
\text { and other components of the water balance (WMO, } \\
\text { 1974, 1982) }\end{array}$ \\
\hline 1981 & $\begin{array}{l}\text { Demonstrated that the } 1960 \text { s rise in lake levels was } \\
\text { caused by natural variability and consecutive heavy } \\
\text { rainfall seasons (Kite, 1981) }\end{array}$ \\
\hline 1984-1994 & $\begin{array}{l}\text { A series of reports to ODA }{ }^{1} \text { (now } \mathrm{FCDO}^{2} \text { ) and } \\
\text { associated papers, reviewing the hydrology of Lake } \\
\text { Victoria, and presenting methodologies for estimating } \\
\text { lake rainfall, evaporation and tributary inflow, } \\
\text { including the use of stochastic techniques, and using a } \\
\text { simple conceptual model to extend the monthly lake } \\
\text { water balance back to 1925, and annual lake water } \\
\text { balance back to } 1900 \text { (Institute of Hydrology, 1984, } \\
\text { 1985, 1993; Piper et al., 1986; Sene and Plinston, 1994) }\end{array}$ \\
\hline 1996 & $\begin{array}{l}\text { Used } 3 \text { GCMs to drive a lake water balance model to } \\
\text { investigate impacts of climate change on Nile flows } \\
\text { (Conway and Hulme, 1996) }\end{array}$ \\
\hline 1998-2001 & $\begin{array}{l}\text { Reconstructed lake level trends back to 1780s using } \\
\text { historical witness accounts and reports of } \\
\text { meteorological conditions, and interpreted the trends } \\
\text { in terms of components of water balance (Yin and } \\
\text { Nicholson, 1998; Nicholson and Yin, 2001) }\end{array}$ \\
\hline 2002 & $\begin{array}{l}\text { Report to LVBC updating lake water balance (COWI } \\
\text { Consulting Engineers and Planners AS, 2002) }\end{array}$ \\
\hline 2004 & $\begin{array}{l}\text { Updated water balance to } 2000 \text {, and did sensitivity } \\
\text { analysis of levels and outflows to climate change (Tate } \\
\text { et al., 2004) }\end{array}$ \\
\hline 2008 & $\begin{array}{l}\text { Applied SWAT }{ }^{3} \text { model to Nzoia tributary using } \\
5 \text { GCMs with focus on climate change impacts on } \\
\text { catchment high flows (Githui et al., 2008) }\end{array}$ \\
\hline 2011 & $\begin{array}{l}\text { Applied } \mathrm{VHM}^{4} \text { and NAM }{ }^{5} \text { models to Nyando } \\
\text { tributary using } 17 \text { GCMs with focus on catchment } \\
\text { hydrological extremes (Taye et al., 2011) }\end{array}$ \\
\hline 2017 & $\begin{array}{l}\mathrm{AGU}^{6} \text { conference presentation describing application } \\
\text { of GR } 4 \mathrm{~J}^{7} \text { model to Katonga tributary using CP4A }{ }^{8} \\
\text { climate data (Stratton et al., 2018; Macdonald et al., } \\
2017 \text { ) }\end{array}$ \\
\hline 2018 & $\begin{array}{l}\text { Tested lake water balance for recent past climate then } \\
\text { applied ensemble of } 6 \mathrm{CORDEX}^{9} \mathrm{RCMs}^{10} \text { to quantify } \\
\text { future levels and outflows (Vanderkelen et al., 2018a, b) }\end{array}$ \\
\hline 2019 & $\begin{array}{l}\text { Weighted and post-processed remote sensing satellite } \\
\text { products to quantify components of water balance } \\
\text { (Khaki and Awange, 2019) }\end{array}$ \\
\hline
\end{tabular}

${ }^{1}$ ODA: Overseas Development Administration (UK); ${ }^{2}$ FCDO: Foreign, Commonwealth and Development Office (UK); ${ }^{3}$ SWAT: Soil and Water Assessment Tool; ${ }^{4}$ VHM: Dutch abbreviation for "generalized lumped conceptual and parsimonious model structure identification and calibration"; ${ }^{5}$ NAM: Nedbør-Afstrømnings-Model; ${ }^{6}$ AGU: American Geophysical Union; ${ }^{7}$ GR4J: "modèle du Génie Rural à 4 paramètres Journalier"; ${ }^{8}$ CP4A: Pan-African Convection-Permitting Regional Climate Simulation with the Met Office Unified Model (UM); ${ }^{9}$ CORDEX: Coordinated Regional Climate Downscaling Experiment; ${ }^{10}$ RCM: Regional Climate Model.

\subsection{Newer techniques from recent applications}

\subsubsection{Climate change studies}

One key application of water balance models has been to help understand whether sudden changes in water levels were due to climatic or other causes.

For example, based on this approach, the sudden rise in levels in the period 1961-1964 has been widely attributed to increased rainfall in East Africa at that time, rather than to other factors such as dam operations (e.g. Piper et al., 1986; Yin and Nicholson, 1998; Sutcliffe and Parks, 1999). Water balance models have also suggested that the sudden fall in levels around 2005 was caused by a drier climatic period and increased releases at Nalubaale Dam (Sutcliffe and Petersen, 2007).

Water balance models can also be used to estimate future levels, with the potential impacts of climate change of particular interest. The earliest studies were typically based on simple scaling factors for rainfall from a single climate model, but nowadays a more sophisticated approach is used. For example, one of the most recent (NCSU et al., 2018) describes the application of change factors from an ensemble of 36 General Circulation Models (GCMs) under a high emissions scenario (Representative Concentration Pathway RCP08.5) to estimate future impacts on lake rainfall, lake evaporation and tributary inflows for input to a water balance model. Houghton-Carr et al. (2021a, b) also describe stochastic modelling approaches that generated many possible future sequences of climate-modified NBS.

An important point is that many of the current regional atmospheric models do not explicitly represent Lake Victoria (NCSU et al., 2018). For example, Thiery et al. (2016) have shown that temperature differences between the lake and surrounding land affect the strength of the lake-land breeze and, hence, the storms and precipitation that occur on and around the lake. As a result, one current research priority is to represent the rainfall due to convective storms over the lake in GCMs.

\subsubsection{Lake operating rules}

For hydropower operations, the outflows from Lake Victoria are governed by an internationally agreed relationship between lake levels and outflows. This is called the Agreed Curve and is designed to mimic the behaviour of the natural lake, before hydropower operations first began.

In recent years, proposed changes to the operating rules for Nalubaale Dam have led to further in-depth studies of the lake outflow characteristics (Houghton-Carr et al., 2021b). As part of these studies, one innovation has been to extend existing models to consider additional terms not usually included, such as water abstractions, allowing rapid assessment of the implications of increases in water use for domestic, agricultural and industrial water use. However, NCSU et al. (2018) demonstrate the potential effect of future changes 
in abstraction to be relatively minor compared to the possible impact of future changes in climate.

\subsubsection{Seasonal flow forecasting}

Another developing area is that of seasonal flow forecasting with operational or pre-operational systems now running in several countries at a regional or national scale.

For Lake Victoria, some forecasting challenges include the additional rainfall generated by the lake, its huge catchment area, and the availability of real-time data. In contrast, the large storage in the lake provides some persistence in outflows, which can be exploited in a seasonal forecasting model.

To explore some key drivers on lake response, Sene et al. (2018) used a data-driven approach to derive stochastic estimates for future lake levels and outflows, which demonstrated forecast skill several months ahead. Some innovative features included use of a data assimilation component, incorporating climate indices, and interpretation of the results using performance metrics better suited to the non-stationary response than more conventional measures. The climate indices chosen were linked to the El Niño Southern Oscillation and the Indian Ocean Dipole, which are the primary known drivers of East African inter-annual rainfall variability.

The potential for seasonal flow forecasting for the Nile has also been explored using indices representative of the Pacific and Indian Oceans (Siam and Eltahir, 2015). More generally, there have been many investigations into the links between regional rainfall and atmospheric and ocean conditions using both statistical and atmospheric modelling approaches (e.g. Nicholson, 2017). Looking to the future, the Lake Victoria basin is also a pilot project under the WMO Hydrological Status and Outlooks (HydroSOS) initiative (https: //public.wmo.int/en, last access: 25 October 2021).

\section{Conclusions}

When considering the history of hydrological studies of Lake Victoria, there is much to celebrate, from innovations in estimating the water balance and the early adoption of stochastic techniques, to increasing recognition of the utility of remote sensing information across data-sparse regions and the embracing of basin-wide solutions through the auspices of the LVBC and others. The development and application of hydrological science in the basin has evolved as new data sources and more advanced computing techniques have become available.

One fundamental challenge is that, due to the lake dynamics, long-term records are required to understand its response, spanning many decades. This requires long, good quality observational records and a common recommendation in many of the studies cited here is the need to improve monitoring, whether ground-based and/or by satellite; and the need for further research to fill gaps in observations in both regional meteorology and hydrology, particularly for the lake rainfall and tributary inflows. This can also reduce uncertainties to improve decision-making going forward, helping to inform a risk-based approach combining probabilities and consequences.

Another priority is to improve forecasting skill at a range of timescales, from short-range weather forecasting to seasonal flow forecasting. Improved climate change impact projections are also required over timescales of years and decades ahead. Internationally, there is an increasing emphasis on a seamless approach, using the same or mutually consistent models and datasets at all timescales.

The challenges and issues faced for Lake Victoria are common to many regions and include the impacts of climate change and human intervention on water resources. In the Lake Victoria region these are compounded by rapid urbanisation, growing population and their associated water demands, and unsustainable exploitation of resources.

These themes are strongly endorsed by evolving ideas from international research programmes, such as the GEWEX (Global Energy and Water Exchanges programme) HyVic project (2012-present), the IAHS (International Association of Hydrological Sciences) Decade on Predictions in Ungauged Basins (PUB; 2003-2012) and the UNESCO (United Nations Educational, Scientific and Cultural Organization) Flow Regimes from International Experimental and Network Data programme (FRIEND-Water; 1984-present). In particular, these emphasise the need for a cooperative approach to the management of the water resources of international river basins, including the free exchange of data, information, expertise and ideas.

Some of the key challenges for practitioners are how future change will affect water resources, and what adaptation strategies are available to best equip key stakeholders. The recent and ongoing unprecedented changes in climate and population in the Lake Victoria basin, and the associated pressures on and demands for water and other natural resources, have driven the requirement for state-of-the-art scientifically-based assessments of the status and future impacts of various environmental and socio-economic change scenarios on water resources, to inform robust, coherent basin management plans. These issues apply to other sub Saharan/Rift Valley lakes too.

Data availability. No data sets were used in this article.

Author contributions. This paper draws on previous research by KS and HHC on the water balance of Lake Victoria, with contributions on approaches to seasonal flow forecasting from WT.

Competing interests. The contact author has declared that neither they nor their co-authors have any competing interests. 
Disclaimer. Publisher's note: Copernicus Publications remains neutral with regard to jurisdictional claims in published maps and institutional affiliations.

Special issue statement. This article is part of the special issue "Hydrology of Large River Basins of Africa". It is a result of the 4th International Conference on the "Hydrology of the Great Rivers of Africa", Cotonou, Benin, 13-20 November 2021.

Acknowledgements. The UKCEH and NCSU studies cited were based on work funded by UK Aid through the Corridors for Growth Trust Fund administered by the World Bank, and on work funded by the Lake Victoria Basin Commission. The views expressed are the authors' own, and not necessarily those of the funding agencies or of any of the Nile basin countries.

Financial support. The support of the Lancaster Environment Centre and the UK Centre for Ecology \& Hydrology in preparing this paper is gratefully acknowledged.

\section{References}

Conway, D. and Hulme, M.: The Impacts of Climate Variability and Future Climate Change in the Nile Basin on Water Resources in Egypt, Int. J. Water Res. Dev., 12, 277-296, https://doi.org/10.1080/07900629650178, 1996.

COWI Consulting Engineers and Planners AS, in association with DHI Water and Environment: Integrated Water Quality/Limnology Study for Lake Victoria: Final Report, COWI, Copenhagen, Denmark, 2002.

De Baulny, H. L. and Baker, D. L.: The water balance of Lake Victoria, Technical Note, Uganda Ministry of Water Development, Entebbe, 1970.

Githui, F., Gitau, W., Mutua, F., and Bauwens, W.: Climate change impact on SWAT simulated streamflow in western Kenya, Int. J. Climatol., 29, 1823-1834, https://doi.org/10.1002/joc.1828, 2008.

Houghton-Carr, H. A., Farquharson, F. A. K., Plinston, D. T., Matano, A. S., Canangire, C., Mwinjaka, O., Okurut, T., and Sutcliffe, J. V.: The development of a new water release and abstraction policy for the Lake Victoria basin, in preparation, 2021a.

Houghton-Carr, H. A., Smith, K., Plinston, D., Marsham, J., Farquharson, F., Finney, D., Ascott, M., Rowell, D., Semazzi, F., and Vanderkelen, I.: Plausible ranges of Lake Victoria level and outflow for decision-making under climate change, in preparation, 2021 b.

Hurst, H. E. and Phillips, P.: The Nile Basin Vol. 5: The Hydrology of the Lake Plateau and Bahr El Jebel, Paper No. 35, Ministry of Public Works Physical Department, Egypt, 1938.

Institute of Hydrology: A review of the hydrology of Lake Victoria and the Victoria Nile, Institute of Hydrology, Wallingford, 1984.

Institute of Hydrology: Further review of the hydrology of Lake Victoria, Institute of Hydrology, Wallingford, 1985.
Institute of Hydrology: Review and update of the water balance of Lake Victoria in East Africa, Institute of Hydrology, Wallingford, 1993.

Khaki, M. and Awange, J.: Improved remotely sensed satellite products for studying Lake Victoria's water storage changes, Sci. Toal Environ., 652, 915-926, https://doi.org/10.1016/j.scitotenv.2018.10.279, 2019.

Kite, G. W.: Recent changes in level of Lake Victoria, Hydrol. Sci. Bull., 26, 233-243, https://doi.org/10.1080/02626668109490883, 1981.

Macdonald, D., Ascott, M., Lapworth, D., and Tindimugaya, C.: Application of scenario-neutral methods to quantify impacts of climate change on water resources in East Africa, in: AGU Fall Meeting 2017, New Orleans, USA, available at: http://nora.nerc. ac.uk/id/eprint/519528/ (last access: 25 October 2021), 2017.

NCSU - North Caroline State University, CEH - Centre for Ecology \& Hydrology, and University of Leeds: Lake Victoria Levels under a Changing Climate, WP1 Report: Analysis of Historical Lake Levels, WP2 Report: Lake Levels under Climate Change, WP3 Report: Recommendations for Future Research and Monitoring to Support Decision-Making, World Bank, Washington, 2018.

Nicholson, S. E.: Climate and climatic variability of rainfall over eastern Africa, Rev. Geophys., 55, 590-635, https://doi.org/10.1002/2016RG000544, 2017.

Nicholson, S. E. and Yin, X.: Rainfall Conditions in Equatorial East Africa during the Nineteenth Century as Inferred from the Record of Lake Victoria, Climatic Change, 48, 387-398, https://doi.org/10.1023/A:1010736008362, 2001.

Piper, B. S., Plinston, D. T. and Sutcliffe, J. V.: The water balance of Lake Victoria, Hydrolog. Sci. J., 31, 25-37, https://doi.org/10.1080/02626668609491025, 1986.

Sene, K., Tych, W., and Beven, K.: Exploratory studies into seasonal flow forecasting potential for large lakes, Hydrol. Earth Syst. Sci., 22, 127-141, https://doi.org/10.5194/hess-22-1272018, 2018.

Sene, K. J. and Plinston, D. T.: A review and update of the hydrology of Lake Victoria in East Africa, Hydrolog. Sci. J., 39, 47-63, https://doi.org/10.1080/02626669409492719, 1994.

Siam, M. S. and Eltahir, E. A. B.: Explaining and forecasting interannual variability in the flow of the Nile River, Hydrol. Earth Syst. Sci., 19, 1181-1192, https://doi.org/10.5194/hess-19-11812015, 2015.

Stratton, R. A., Senior, C. A., Vosper, S. B., Folwell, S. S., Boutle, I. A., Earnshaw, P. D., Kendon, E., Lock, A. P., Malcolm, A., Manners, J., Morcrette, C. J., Short, C., Stirling, A. J., Taylor, C. M., Tucker, S., Webster, S., and Wilkinson, J. M.: A Pan-African Convection-Permitting Regional Climate Simulation with the Met Office Unified Model: CP4-Africa, J. Climate, 31, 34853508, https://doi.org/10.1175/JCLI-D-17-0503.1, 2018.

Sutcliffe, J. V. and Parks, Y. P.: The Hydrology of the Nile, IAHS Special Publication no. 5, IAHS Press, Wallingford, 192 pp., ISBN 978-1-901502-75-6, 1999.

Sutcliffe, J. V. and Petersen, G.: Lake Victoria: derivation of a corrected natural water level series, Hydrolog. Sci. J., 52, 13161321, https://doi.org/10.1623/hysj.52.6.1316, 2007.

Tate, E., Sutcliffe, J., Conway, D., and Farquharson, F.: Water balance of Lake Victoria: update to 2000 and climate 
change modelling to 2100, Hydrolog. Sci. J., 49, 563-574, https://doi.org/10.1623/hysj.49.4.563.54422, 2004.

Taye, M. T., Ntegeka, V., Ogiramoi, N. P., and Willems, P.: Assessment of climate change impact on hydrological extremes in two source regions of the Nile River Basin, Hydrol. Earth Syst. Sci., 15, 209-222, https://doi.org/10.5194/hess-15-209-2011, 2011.

Thiery, W., Davin, E. L., Seneviratne, S. I., Bedka, K., Lhermitte, S., and van Lipzig, N. P. M.: Hazardous thunderstorm intensification over Lake Victoria, Nat. Commun., 7, 12786, https://doi.org/10.1038/ncomms12786, 2016.

Vanderkelen, I., van Lipzig, N. P. M., and Thiery, W.: Modelling the water balance of Lake Victoria (East Africa) - Part 1: Observational analysis, Hydrol. Earth Syst. Sci., 22, 5509-5525, https://doi.org/10.5194/hess-22-5509-2018, 2018a.

Vanderkelen, I., van Lipzig, N. P. M., and Thiery, W.: Modelling the water balance of Lake Victoria (East Africa) - Part 2: Future projections, Hydrol. Earth Syst. Sci., 22, 5527-5549, https://doi.org/10.5194/hess-22-5527-2018, 2018 b.
WMO - World Meteorological Organisation: Hydrometeorological survey of the catchments of lakes Victoria, Kyoga and Albert: Burundi, Egypt, Kenya, Rwanda, Sudan, United Republic of Tanzania and Uganda: Vol. 1 Meteorology and hydrology of the basin, World Meteorological Organisation report, Geneva, Switzerland, 1974.

WMO - World Meteorological Organisation: Hydrometeorological survey of the catchments of lakes Victoria, Kyoga and Mobutu Sese Seko: project findings and recommendations, World Meteorological Organisation report, Geneva, Switzerland, 1982.

Yin, $X$. and Nicholson, S. E.: The water balance of Lake Victoria, Hydrolog. Sci. J., 43, 789-811, https://doi.org/10.1080/02626669809492173, 1998. 